\title{
The Effect of Serum Bone Sialoprotein Levels on Tympanosclerosis
}

\author{
Serum Kemik Sialoprotein Seviyelerinin Timpanoskleroza Etkisi
}

\section{(D) Ahmet BAKİ ${ }^{1}$, iD Muhammet YILDIZ², iD Ömer Faruk ÖZER³, io Hifa Gülru ÇAĞLAR3}

1 Üsküdar State Hospital, Clinic of Otolaryngology, İstanbul, Turkey

${ }^{2}$ Antalya Training and Research Hospital, Clinic of Otolaryngology, Antalya, Turkey

${ }_{3}^{3}$ Bezmialem Vakıf University Faculty of Medicine, Department of Biochemistry, İstanbul, Turkey

\section{ABSTRACT}

Objective: This study aimed to investigate serum bone sialoprotein (BSP) levels in patients with tympanosclerosis (TS).

Methods: We included into this study 24 patients with TS and 24 asymptomatic healthy volunteers. Our study consisted of two groups: TS group ( $\mathrm{n}=24)$, comprising of patients who underwent surgery for chronic otitis media and had tympanosclerotic plaques; and a control group $(\mathrm{n}=24)$, comprising of healthy individuals without ear problems. The serum BSP levels were measured and the results were compared between the two groups.

Results: In the TS group, there were 15 female and nine male patients. The ages of the females ranged from 24 to 54 years, while those of the males ranged from 34 to 55 years; the average age was $40.46 \pm 9.75$ and $43.11 \pm 6.77$, respectively. In the control group, there were 14 females and ten males. The ages of the females ranged from 30 to 48 years, while those of the males ranged from 27 to 47 years; the average age was $40.25 \pm 5.28$ and $38.4 \pm 27.08$, respectively. There was a statistically significant difference in BSP levels between the two groups $(\mathrm{p}=0.001)$. In addition, there was a moderate positive correlation between BSP and hearing levels.

Conclusion: The serum BSP levels were higher in the TS group than in the control group and might have some effect on TS. Further studies on a large number of subjects using serum and tissue BSP levels should be designed to affirm the effects of BSP on TS.

Keywords: Timpanosclerosis, bone sialoprotein, calcification

\section{ÖZ}

Amaç: $\mathrm{Bu}$ çalışmanın amacı timpanoskleroz (TS) hastalarında serum bone sialoprotein (BSP) seviyelerini araştırmaktır.

Yöntemler: Yirmi dört TS hastası ve 24 asemptomatik sağlıklı gönüllü çalışmaya dahil edildi. Çalışmamızda iki grup vardı: kronik otitis media ameliyatı geçirmiş ve timpanosklerotik plakları olan hastalardan oluşan TS grubu (24); ve kulak problemi olmayan sağlıklı bireylerden oluşan kontrol grubu $(n=24)$. Serum BSP seviyeleri ölçüldü ve sonuçlar iki grup arasında karşılaştırıldı.

Bulgular: Timpanoskleroz grubunda 15 kadın ve 9 erkek hasta vardı. Kadınların yaşları 24 ile 54 arasında değişirken, erkeklerin yaşları 34 ile 55 arasında değişmekteydi ve yaş ortalaması sırasıyla $40,46 \pm 9,75$ ve $43,11 \pm 6,77$ idi. Kontrol grubunda 14 kadın ve 10 erkek vardı. Kadınların yaşları 30 ile 48 arasında değişirken, erkeklerin yaşları 27 ile 47 arasında değişmekteydi ve yaş ortalaması sırasiyla $40,25 \pm 5,28$ ve $38,4 \pm 27,08$ olarak saptandı. BSP düzeyleri karşılaştırıldığında iki grup arasında istatistiksel olarak anlamlı fark bulundu ( $\mathrm{p}=0,001)$. Ek olarak, BSP ile işitme seviyeleri arasında pozitif orta düzeyde bir korelasyon vardı.

Sonuç: Serum BSP düzeyleri TS grubunda kontrol grubundan daha yüksekti ve TS üzerinde bir etkisi olabilir. Çok sayıda hasta üzerinde serum ve doku BSP seviyelerini araştıran yeni çalışmalar, BSP'nin TS üzerindeki etkilerini doğrulamak için tasarlanmalıdır.

Anahtar Sözcükler: Timpanoskleroz, kemik sialoprotein, kalsifikasyon

Address for Correspondence: Ahmet BAKi, Üsküdar State Hospital, Clinic of Otolaryngology, İstanbul, Turkey

E-mail: dr.ahmet170@gmail.com ORCID ID: orcid.org/0000-0003-2851-0849 


\section{Introduction}

Tympanosclerosis (TS) is a chronic middle ear disease that manifests as collagen accumulation in the tympanic membrane lamina propria and mastoid cavity submucosa and also affecting auditory ossicles (1). This disease involves the development of calcified plaques in the submucosal area of the middle ear, due to calcification of the connective tissue layer pathologically. Regarding the situation of calcification, we can observe by electron microscopy a network of intense collagen fibers with scattered crystalline material, which is fundamentally calcium phosphate. It is thought that the calcium phosphate clusters are formed by deposition of the mineral on the surface of matrix vesicles, which acts as primary sites of calcification $(1,2)$. These changes often disrupt the movement of the eardrum and the ossicular chain, leading to hearing loss.

Although the etiology of TS is still not fully understood, it is widely believed that it commonly develops secondary to acute or chronic inflammation of the middle ear and as a result of other factors such as myringotomy, ventilation tube insertion, physical trauma, various chemical agent exposure, genetic predispositions, immunological processes and hypercalcemia (3).

Bone sialoprotein (BSP) is one of the most important extracellular matrix (ECM) proteins of the bone and belongs to the small integrin-binding ligand $\mathrm{N}$-linked glycoprotein family. This family consists of BSP, dentin sialophosphoprotein, osteopontin (OPN), matrix extracellular phosphoglycoprotein and dentin matrix protein-1 that are believed to play crucial biological roles in the turnover, improvement and mineralization of dentin and bone $(4,5)$. Although BSP is usually expressed in mineralized tissues and has been proposed to have a direct role in mineralization, the protein has currently been shown to be expressed in varied tissues including renal tissues, salivary glands and in pathological conditions such as tumours (6-8).

OPN is a hormone that is a regulator of biomineralization and inflammation and is also known as BSP I. Several studies have shown that OPN is upregulated in pathological ectopic calcification and tympanosclerotic focusing regions $(9,10)$. Although the relationship between osteopontin and TS is known, the relationship between BSP and TS has not been investigated before. In this study, the serum BSP levels were evaluated in TS patients.

\section{Methods}

Following approval by the local ethics committee (Protocol number: 110, Date: 27.06.2018), the study was conducted in the Uskudar State Hospital Otolaryngology Clinic. Twenty-four patients who were diagnosed with chronic otitis media between July 2018 and March 2019 were included in the study. Patients with otorrhea, otitis media with effusion, acute otitis media, and chronic systemic disease were excluded. There were 48 participants: groups of 24 patients and 24 controls. The control group had no ear problems and no chronic systemic disease. There were 15 females and nine males in the patient group and the mean age was $40.46 \pm 9.75$ and $43.11 \pm 6.77$ years, respectively.
There were 14 females and ten males in the control group and the mean age was $40.25 \pm 5.28$ and $38.4 \pm 27.08$, respectively (Table 1).

\section{Sampling \\ Serum Bone Sialoprotein Levels}

Serum BSP levels were evaluated using with a human enzymelinked immunosorbent assay kit (lot no.: AK0018JAN10047; Elabscience, Wuhan, Hubei, PRC) and a Multiskan plate reader. (Thermo Scientific, Waltham, MA, USA). Anti-Human BSP antibodies in pre-covered 96-well plates were used. The biotinconjugated anti-Human BSP antibodies were used as detection antibodies. Test samples, biotin-conjugate detection antibodies and standards were washed with the wash buffer after addition to wells. The samples and standards were analysed in duplicates as demonstrated in the kit package suffix.

Horseradish peroxidase (HRP)-Streptavidin was added to the unconjugated conjugates and further washed with washing buffer. TMB (tetramethylbenzidine) was catalysed with HRP to generate a blue colour product that turned yellow when the acidic stop solution was added. The quantity of Human BSP captured on the plate is proportional to the intensity of the yellow colour. The absorbances were read at $450 \mathrm{~nm}$ in a microplate reader and then the Human BSP concentrations were calculated according to the standard curve. The other serum parameters were examined using a Beckman Coulter AU 2700 Device (California, USA) and the spectrophotometric method.

Calibration was done with seven standards in the kit. The standards at $40,20,10,5,2.5,1.25$ and $0.63 \mathrm{ng} / \mathrm{mL}$ concentrations were ran twice and the standard curve was created. The standard curve was obtained in a similar manner to the shape recommended in the kit package insert. A well was separated as a blank well.

Biochemical Analysis: Total BSP (ng/mL) levels were measured from the serum samples of the patients.

The blood of the patients and the control group were centrifuged $\left(10 \mathrm{~min}\right.$ at $\left.2,500 \times \mathrm{g}, 4^{\circ} \mathrm{C}\right)$. Serum samples were stored in Eppendorf tubes at $-80^{\circ} \mathrm{C}$ until tested.

\section{Statistical Analysis}

In this study, IBM SPSS Statistics Version 22 software package was used for the statistical analysis. Shapiro-Wilks test was used for the normal distribution suitability of the parameters. Descriptive statistical methods (Mean, standard deviations and median values) were calculated. Mann-Whitney $U$ test was used in the comparison of nonparametric data between groups. Significance was assessed at $\mathrm{p}<0.05$ level. Spearman's correlation test was used in the correlation test performed between the hearing level and BSP level.

\section{Results}

The right side air and bone hearing levels of the patient group were $45.7 \pm 20.37 \mathrm{~dB}$ and $19.04 \pm 11.29 \mathrm{~dB}$ and the left side air and bone hearing levels were $40.54 \pm 21.69 \mathrm{~dB}$ and $17.54 \pm 12 \mathrm{~dB}$, respectively (Table 1). 
The right side air and bone hearing levels of the control group were $12.59 \pm 5.01 \mathrm{~dB}$ and $9.86 \pm 4.27 \mathrm{~dB}$ and left side air, and bone hearing levels were $13.31 \pm 5.42 \mathrm{~dB}$ and $9.77 \pm 4.51 \mathrm{~dB}$, respectively (Table 1).

The mean serum BSP levels of the patient and control groups were $28.8 \pm 4.4(\mathrm{ng} / \mathrm{mL})$ and $24.1 \pm 4.9(\mathrm{ng} / \mathrm{mL})$, respectively. Statistical analysis of the patient and control groups revealed that serum BSP levels were significantly higher in the patient group compared to the control group $(\mathrm{p} \leq 0.001)$ (Table 2).

There was a moderate positive correlation between BSP and severity of hearing loss in the patient group $\left(r=0.49 ; \quad r^{2}=0.319\right.$; $\mathrm{p}=0.01)($ Graphic 1).

\section{Discussion}

TS is a disease characterised by hyaline calcareous plaques in the tympanic membrane and tympanic space. It may be located in the ossicular chain, ligaments and sometimes in the mastoid. It is an irreversible disease that occurs as a sequelae of a poor inflammatory process in the case of a long-lasting chronic otitis media (11). The inflammatory state occurring in the middle ear mucosa progresses towards an abnormal scarring process characterised by hyalinisation, calcification and osteogenesis. These changes often disrupt the movement of the eardrum and ossicular chain, leading to hearing loss (12).

\begin{tabular}{l|l|l|l|}
\multicolumn{3}{|c}{ Table 1. Demographic data of the patient and control } \\
groups
\end{tabular}

$\mathrm{N}$ : Number of patients, SD: Standard deviation, dB: Decibel, min: Minimum, Max: Maximum
BSP is produced by osteoclasts, chondrocytes and osteoblasts and it is an important ECM protein (13-15). It was suggested to be physiologically significant for hydroxyapatite nucleation and mineralization $(16,17)$. Although BSP does not contain different structural areas, the protein is highly modular, comprising spatially segmented motifs that can bind varied distinct ECM components with various biological roles, including collagen, matrix metalloproteinases, hydroxyapatite, as well as integrins present on many cell types (18-21). BSP might have a versatile act in the progress of the mineralized tissue. Spatiotemporal expression of BSP in de novo mineralization areas correlated with BSP at the start of mineralization $(14,22)$. In addition, BSP is expressed at pathological areas of mineralization such as microcalcifications in the breast, atherosclerotic plaques, prostate and thyroid neoplasms $(8,23-25)$. It is known that the basic pathology in tympanosclerotic tissues is excessive calcified hyaline plaques and pathological mineralization. There is no previous study in the literature investigating BSP levels in patients with TS. In our study, serum BSP levels were remarkably higher in the TS group than in the control group.

BSP is a highly post-translationally modified acidic phosphoprotein normally expressed in mineralized tissues such as dentin and bone (26). BSP was suggested to be physiologically important for hydroxyapatite nucleation, cell cohesion and collagen binding $(16,17)$. BSP gene ablated mice with various skeletal and dental defects had decreased bonelength and decreased cortical density $(27,28)$. BSP gene-ablated mice also showed a delay in bone repair in cortical injury models; bone formation and absorption were also found to be impaired in bone marrow ablation models $(29,30)$. Cementum is a mineralized tissue in the

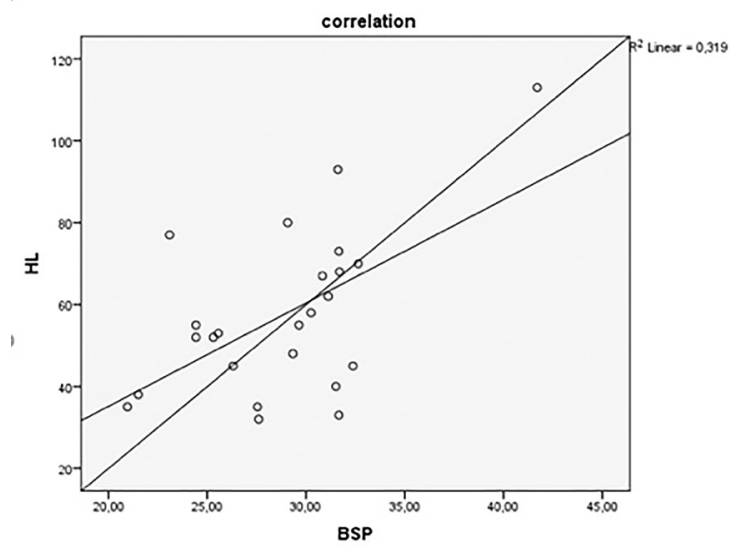

Graphic 1. BSP: Bone sialoprotein, HL: Hearing level (moderate positive correlation between BSP and $\mathrm{HL}$ )

Table 2. Comparison of serum bone sialoprotein levels between patient and control groups

\begin{tabular}{|c|c|c|c|c|c|}
\hline & $\mathrm{N}$ & Min & Max & Mean \pm SD & $p$ \\
\hline Patient & 24 & $20.96(\mathrm{ng} / \mathrm{mL})$ & 41.7 (ng/mL) & $28.8 \pm 4.4(\mathrm{ng} / \mathrm{mL})$ & \\
\hline Control & 24 & 6.01 (ng/mL) & 29.62 (ng/mL) & $24.1 \pm 4.9(\mathrm{ng} / \mathrm{mL})$ & \\
\hline
\end{tabular}

Mann-Whitney $U$ test $p \leq 0.05$, SD: Standard deviation, ng: Nanogram 
cervical part of the root of the tooth. In immunohistochemical studies, a significant reduction in cementum accumulation was observed in BSP gene ablation mice (31).

BSP has been involved in the reparation of several mineralized tissues. Bone formation was observed when BSP and collagen implantation were performed in 7-8-week old rats with calvarial deficiency (32). Cortical default drilled into the femurs of BSPablated mice gets well slowly when compared to controls (33).

In a study comparing patients with metabolic bone disease and a healthy control group, serum BSP concentrations were found to be remarkably higher in patients with the metabolic disease. The highest concentrations were found in patients with active Paget's disease and secondary renal hyperparathyroidism (34).

In some studies, it has been suggested that osteoblast cultures can interfere with osteoblast binding through the selection of lowexpressing clones or by the addition of an anti-BSP and that the antibody may have a negative effect on osteoblast distinction by changing BSP levels. This condition is presumably due to the breaking down of osteoblast differentiation (35-38).

In our study, we compared the serum BSP levels between the patient and the control group because we think that BSP plays an active role in tissue mineralization and calcification. In this study, serum BSP levels were significantly higher in the TS group than in the control group and there was a moderate positive correlation between BSP and hearing levels. The limitations of our study were that the number of patients was low and the amount of BSP at the tissue level was not measured.

\section{Conclusion}

The serum BSP levels were significantly higher in the TS group than in the control group. There was a moderate positive correlation between BSP and hearing levels. In the future, the manipulation of local BSP levels may be useful in the treatment of TS.

\section{Ethics}

Ethics Committee Approval: Following approval by the Local Ethics Committee (Protocol number: 110, Date: 27.06.2018), the study was conducted in the Uskudar State Hospital Otolaryngology Clinic.

Informed Consent: Written informed consent was obtained from the patients.

Peer-review: Internally and externally peer reviewed.

\section{Authorship Contributions}

Surgical and Medical Practices: A.B., Concept: A.B., Design: A.B., Data Collection or Processing: A.B., Ö.F.Ö., H.G.Ç., Analysis or Interpretation: A.B., M.Y., Ö.F.Ö., H.G.Ç., Literature Search: A.B., M.Y., Writing: A.B., M.Y.

Conflict of Interest: No conflict of interest was declared by the authors.
Financial Disclosure: The author(s) disclosed receipt of the following financial support for the research, authorship, and/or publication of this article: This work was supported by Meders company and Ser-Med medical.

\section{References}

1. de Carvalho Leal M, Ferreira Bento R, da Silva Caldas Neto S, Caldas N, Alves Peixoto C, Delgado Lessa FJ, et al. Influence of hypercalcemia in the formation of tympanosclerosis in rats. Otol Neurotol 2006;27:27-32.

2. Hasegawa T. Ultrastructure and biological function of matrix vesicles in bone mineralization. Histochem Cell Biol 2018;149:289-304.

3. Mattsson C, Magnuson K, Hellström S. Myringosclerosis caused by increased oxygen concentration in traumatized tympanic membranes. Experimental study. Ann Otol Rhinol Laryngol 1995;104:625-32.

4. Fisher LW, Torchia DA, For B, Young MF, Fedarko NS. Flexible structures of SIBLING proteins, bone sialoprotein, and osteopontin. Biochem Biophys Res Commun 2001;280:460-5.

5. Qin C, Baba O, Butler WT. Post-translational modifications of sibling proteins and their roles in osteogenesis and dentinogenesis. Crit Rev Oral Biol Med 2004;15:126-36.

6. Ogbureke KUE, Fisher LW. Expression of SIBLINGs and their partner MMPs in salivary glands. J Dent Res 2004;83:664-70.

7. Ogbureke KUE, Fisher LW. Renal expression of SIBLING proteins and their partner matrix metalloproteinases (MMPs). Kidney Int 2005;68:155-66.

8. Waltregny D, Bellahcene A, de Leval X, Florkin B, Weidle U, Castronovo V. Increased expression of bone sialoprotein in bone metastases compared with visceral metastases in human breast and prostate cancers. J Bone Miner Res 2000;15:834-43.

9. Kim HS, Shin HI, Lim HS, Lee TY, Lee K, Jeong D. $\alpha$-Lipoic acid attenuates coxsackievirus B3-induced ectopic calcification in heart, pancreas, and lung. Biochem Biophys Res Commun 2013;432:37883.

10. Higgins CL, Isbilir S, Basto P, Chen IY, Vaduganathan M, Vaduganathan P, et al. Distribution of alkaline phosphatase, osteopontin, RANK ligand and osteoprotegerin in calcified human carotid atheroma. Protein J 2015;34:315-28.

11. McKee GJ, Kerr AG. Tympanosclerosis: a scanning electron microscopic study. Clin Otolaryngol Allied Sci 1989;14:11-6.

12. Asiri S, Hasham A, al Anazy F, Zakzouk S, Banjar A. Tympanosclerosis: review of literature and incidence among patients with middle ear infection. J Laryngol Otol 1999;113:1076-80.

13. Fisher LW, McBride OW, Termine JD, Young MF. Human bone sialoprotein. Deduced protein sequence and chromosomal localization. J Biol Chem 1990;265:2347-51.

14. Chen J, Shapiro HS, Sodek J. Development expression of bone sialoprotein mRNA in rat mineralized connective tissues. J Bone Miner Res 1992;7:987-97.

15. Paz J, Wade K, Kiyoshima T, Sodek J, Tang J, Tu Q, et al. Tissue-and bone cell-specific expression of bone sialoprotein is directed by a 9.0 $\mathrm{kb}$ promoter in transgenic mice. Matrix Biol 2005;24:341-52. 
16. Tye CE, Hunter GK, Goldberg HA. Identification of the type I collagen-binding domain of bone sialoprotein and characterization of the mechanism of interaction. J Biol Chem 2005;280:13487-92.

17. Baht GS, Hunter GK, Goldberg HA. Bone sialoprotein-collagen interaction promotes hydroxyapatite nucleation. Matrix Biol 2008;27:600-8.

18. Karadag A, Ogbureke KUE, Fedarko NS, Fisher LW. Bone sialoprotein, matrix metalloproteinase 2, and alpha(v)beta3 integrin in osteotropic cancer cell invasion. J Natl Cancer Inst 2004;96:95665.

19. Goldberg HA, Warner KJ, Li MC, Hunter GK. Binding of bone sialoprotein, osteopontin and synthetic polypeptides to hydroxyapatite. Connect Tissue Res 2001;42:25-37.

20. Grzesik WJ, Robey PG. Bone matrix RGD glycoproteins: immunolocalization and interaction with human primary osteoblastic bone cells in vitro. J Bone Miner Res 1994;9:487-96.

21. Byzova TV, Kim W, Midura RJ, Plow EF. Activation of integrin alpha(V) beta(3) regulates cell adhesion and migration to bone sialoprotein. Exp Cell Res 2000;254:299-308.

22. Chen J, McKee MD, Nanci A, Sodek J. Bone sialoprotein mRNA expression and ultrastructural localization in fetal porcine calvarial bone: comparisons with osteopontin. Histochem J 1994;26:67-78.

23. Bellahcene A, Albert V, Pollina L, Basolo F, Fisher LW, Castronovo V. Ectopic expression of bone sialoprotein in human thyroid cancer. Thyroid 1998;8:637-41.

24. Bellahcene A, Castronovo V. Expression of bone matrix proteins in human breast cancer: potential roles in microcalcification formation and the genesis of bone metastases. Bull Cancer 1997;84:17-24.

25. Dhore CR, Cleutjens JP, Lutgens E, Cleutjens KB, Geusens PP, Kitslaar PJ, et al. Differential expression of bone matrix regulatory proteins in human atherosclerotic plaques. Arterioscler Thromb Vasc Biol 1998;21:1998-2003.

26. Ganss B, Kim RH, Sodek J. Bone sialoprotein. Crit Rev Oral Biol Med 1999;10:79-98.

27. Bouleftour W, Juignet L, Bouet G, Granito RN, Vanden-Bossche A, Laroche N, et al. The role of the SIBLING, Bone Sialoprotein in skeletal biology - Contribution of mouse experimental genetics. Matrix Biol 2016;52:60-77.

28. Malaval L, Wade-Guéye NM, Boudiffa M, Fei J, Zirngibl R, Chen F, et al. Bone sialoprotein plays a functional role in bone formation and osteoclastogenesis. J Exp Med 2008;205:1145-53.
29. Monfoulet L, Malaval L, Aubin JE, Rittling SR, Gadeau AP, Fricain JC, et al. Bone sialoprotein, but not osteopontin, deficiency impairs the mineralization of regenerating bone during cortical defect healing. Bone 2010;46:447-52.

30. Wade-Gueye NM, Boudiffa M, Vanden-Bossche A, Laroche N, Aubin JE, Vico L, et al. Absence of bone sialoprotein (BSP) impairs primary bone formation and resorption: The marrow ablation model under PTH challenge. Bone 2012;50:1064-73.

31. Foster BL, Soenjaya Y, Nociti FH Jr, Holm E, Zerfas PM, Wimer HF, et al. Deficiency in Acellular Cementum and Periodontal Attachment in BSP Null Mice. J Dent Res 2013;92:166-72.

32. Wang J, Zhou HY, Salih E, Xu L, Wunderlich L, Gu X, et al. SiteSpecific In Vivo Calcification and Osteogenesis Stimulated by Bone Sialoprotein. Calcif Tissue Int 2006;79:179-89.

33. Malaval L, Monfoulet L, Fabre T, Pothuaud L, Bareille R, Miraux $S$, et al. Absence of bone sialoprotein (BSP) impairs cortical defect repair in mouse long bone. Bone 2009;45:853-61.

34. Karmatschek M, Maier I, Seibel MJ, Woitge HW, Ziegler R, Armbruster FP. Improved purification of human bone sialoprotein and development of a homologous radioimmunoassay. Clin Chem 1997;43:2076-82.

35. Wang D, Christensen K, Chawla K, Xiao G, Krebsbach PH, Franceschi RT. Isolation and characterization of MC3T3-E1 preosteoblast subclones with distinct in vitro and in vivo differentiation/ mineralization potential. J Bone Miner Res 1999;14:893-903.

36. Gerstenfeld LC, Uporova T, Schmidt J, Strauss PG, Shih SD, Huang LF, et al. Osteogenic potential of murine osteosarcoma cells: comparison of bone-specific gene expression in vitro and in vivo conditions. Lab Invest 1996;74:895-906.

37. Cooper LF, Yliheikkila PK, Felton DA, Whitson SW. Spatiotemporal assessment of fetal bovine osteoblast culture differentiation indicates a role for BSP in promoting differentiation. J Bone Miner Res 1998;13:620-32.

38. Mizuno M, Imai T, Fujisawa R, Tani H, Kuboki Y. Bone sialoprotein (BSP) is a crucial factor for the expression of osteoblastic phenotypes of bone marrow cells cultured on type I collagen matrix. Calcif Tissue Int 2000;66:388-96. 